\title{
Genotypic Differences among Mung Bean (Vigna radiata L.) Genotypes for Yield and Associated Traits
}

\author{
Fahim Ullah Khan ${ }^{1, ~ *, ~ M u h a m m a d ~ K h a n ~}{ }^{2}$, Mirza Hassan $^{3}$, Rozina Gul $^{4}$ \\ ${ }^{1}$ Barani Agricultural Research Station, Kohat, Pakistan \\ ${ }^{2}$ Agricultural Research Station, Bannu, Pakistan \\ ${ }^{3}$ Agriculture Research Fata, Orakzai Agency, Pakistan \\ ${ }^{4}$ Department of Plant Breeding and Genetics, The University of Agriculture, Peshawar, Pakistan
}

\section{Email address:}

fahimbiotech@gmail.com (F. U. Khan)

${ }^{*}$ Corresponding author

\section{To cite this article:}

Fahim Ullah Khan, Muhammad Khan, Mirza Hassan, Rozina Gul. Genotypic Differences among Mung Bean (Vigna Radiata L.) Genotypes for Yield and Associated Traits. International Journal of Applied Agricultural Sciences. Vol. 3, No. 2, 2017, pp. 47-50. doi: $10.11648 /$ j.ijaas.20170302.13

Received: May 15, 2016; Accepted: March 3, 2017; Published: March 21, 2017

\begin{abstract}
Fourteen mung bean genotypes were evaluated at Barani Agricultural Research Station, Kohat during 2014 in randomized complete block design with three replications. Analysis of variance depicted significant differences among genotypes for all the traits studied. Maximum plant height was recorded for genotype VC-6321 $(105.7 \mathrm{~cm})$, pod length for Mung NM-06 (9.7cm), seeds pod ${ }^{-1}$ for NM-19-19 (12), biological yield for NM-92 (13111.1 kgha $\left.{ }^{-1}\right)$, whereas Mung NM11 showed maximum values for pods plant ${ }^{-1}(22.5), 1000$-grain weight $(55.6 \mathrm{~g})$, grain yield $\left(3401.8 \mathrm{~kg} \mathrm{ha}^{-1}\right)$ and harvest index (36.5\%). Genotype Mung NM11 showed highest values pods plant ${ }^{-1}$, 1000-grain weight and grain yield and could be recommended for general cultivation in Kohat region.
\end{abstract}

Keywords: Mung Bean, Genetic Variability, Yield Component, Grain Yield

\section{Introduction}

Mung bean (Vigna radiata L. Wilczek), is one of the important pulse crops, which belongs to genus Vigna, species radiata and family Leguminoseae [1]. Mung bean is usually grown at low to medium elevations in the tropics as a rainfed crop. In spite of its importance as food and feed, very little attention has been paid to its quantitative and qualitative improvement in the country. It is one of the major Rabi/ Kharif pulses and ranks second to chickpea. In Pakistan, it is grown in an area of 256.0 thousand hectares with an annual production of 140.8 thousand tons, and an average seed yield of $550 \mathrm{~kg} \mathrm{ha}^{-1}$ [2]. Area under mung bean cultivation in Pakistan was 136.9 hectare within average production 90 tons per hectare during 2012-13, whereas in Khyber Pakhtunkhwa the mung bean was grown an area of 7.1 hectare within average yield $620 \mathrm{~kg} \mathrm{ha}^{-1}$ [2].

For maintenance and efficient utilization of germplasm, it is important to investigate the extent of genetic variability and its magnitude for the determination of the success of a breeding program [3]. An initial step in a breeding program is the assembly of germplasm with a wide range of genetic variability. The utility of a germplasm collection would be enhanced if the unique features of each genotype were to be described and recorded, so that the researcher could choose those genotypes in the collection, which have the genetic characteristics, desired for his specific objectives [4].

The study of correlation of various traits is very important for crop improvement, because the information on association among various economic traits provides the basis of selection and synthesis of improved cultivars [5]. The knowledge of correlation between various parameters makes it possible for a breeder to draw a selection criteria for genetic improvement of mung bean crop. But before starting mung bean improvement program through single plant selections, it is of dire necessity to have the knowledge of genetic variability and interdependence of various characters 
on grain yield. Keeping in view the above mentioned facts the present experiment was designed to determine genetic variability and trait association studies in mung bean.

\section{Materials and Methods}

The experiment to study genetic variability and correlation in mung bean was conducted at Barani Agricultural Research Station, Kohat during summer 2014. The experimental material including 14 mung bean genotypes, namely KM-1, Chasma-98, Mung NM11, Mung Chakwal-06, Mung NM-06, Mung NCM-257-2, Mung AZRI-06, Mung 97, VC-6321, VC-6369, VC-6370, VC-6368, NM-19-19, and NM-92 were sown on July 10, 2014. A randomized complete block design with three replications was used. Each genotype had 4 rows per plot, with a row length of $4 \mathrm{~m}$ and plant to plant distance $10 \mathrm{~cm}$ and row to row distance of $30 \mathrm{~cm}$. Normal cultural practices were followed during the whole season. Data were recorded on plant height $(\mathrm{cm})$, pod length $(\mathrm{cm})$, pods plant ${ }^{-1}$, seeds pod ${ }^{-1}, 1000$ grain weight $(\mathrm{g})$, biological yield $\left(\mathrm{kg} \mathrm{ha}^{-1}\right)$, grain yield $\left(\mathrm{kg} \mathrm{ha}^{-1}\right)$ and harvest index $(\%)$.

\subsection{Statistical Analysis}

\subsubsection{Analysis of Variance}

Data collected on various traits was subjected to analysis of variance (ANOVA) for randomized complete block design using statistical software Statistix ver. 8.1. Upon significant differences, means were separated using least significance difference (LSD) test at 5\% level of probability.

\subsubsection{Correlation}

Pearson correlation coefficient among yield traits was computed software using Statistix ver. 8.1.

\section{Results and Discussion}

\subsection{Plant Height (cm)}

The analysis of variance showed highly significant differences $(\mathrm{P}=0.01)$ among the genotypes for plant height (Table 1). The coefficient of variance (CV) for plant height was $2.43 \%$. Averaged across genotypes, mean plant height was 88.4 $\mathrm{cm}$. Plant height among mung bean genotypes ranged from 48.7 to $105.7 \mathrm{~cm}$ (Table 2). Minimum plant height was recorded for KM-1 $(48.7 \mathrm{~cm})$ and maximum for genotype VC-6321 $(105.7 \mathrm{~cm})$. The results of current experiment regarding variation in plant height of mung bean genotypes are in accordance with the earlier findings of $[6,7]$.

\subsection{Pod Length (cm)}

The analysis of variance exhibited highly significant differences $(\mathrm{P}=0.01)$ among the genotypes for pod length (Table 1). The coefficient of variance (CV) for pod length was $4.95 \%$. Averaged across genotypes, mean pod length was $8.8 \mathrm{~cm}$. Pod length among mung bean genotypes ranged from 7.2 to $9.7 \mathrm{~cm}$ (Table 2). Minimum pod length was recorded for KM-1 $(7.2 \mathrm{~cm})$ and maximum for genotype Mung NM-06
$(9.7 \mathrm{~cm})$. Earlier studies of $[8,9]$ also reported sufficient variability for pod length in mung bean genotypes.

\subsection{Pods Plant ${ }^{1}$ (no.)}

The analysis of variance showed highly significant differences $(\mathrm{P}=0.01)$ among the genotypes for pod plant ${ }^{-1}$ (Table 1). The coefficient of variance $(\mathrm{CV})$ for pod per plant was $5.74 \%$. Pods plant ${ }^{-1}$ among mung bean genotypes ranged from 15.2 to 22.5. Minimum pods plant $^{-1}$ was recorded for VC-6368 (15.2) and maximum Mung NM11 (22.5). Averaged across genotypes, mean pod length was 18.7 (Table 2). Number of pods is one of the most important yield components that can have much influence on the yield. Reference $[6,10,11]$ also reported significant variation for pods per plant in mung bean.

\subsection{Seeds Pod $^{1}$ (no.)}

The analysis of variance showed highly significant differences $(\mathrm{P}=0.01)$ among the genotypes for seeds $\operatorname{pod}^{-1}$ (Table 1). The coefficient of variance (CV) for seeds pod ${ }^{-1}$ was 3.30. Averaged across genotypes, mean seeds $\operatorname{pod}^{-1}$ were 11.2. Seeds pod ${ }^{-1}$ among mung bean genotypes ranged from 9.3 to 12.0. Minimum seeds pod $^{-1}$ was recorded for NM-92 (9.3) and maximum NM-19-19 (12.0) (Table 2). The results of current studies are in accordance with the earlier findings of $[12,13,21]$.

\subsection{0-Grain Weight (g)}

The analysis of variance expressed highly significant differences $(\mathrm{P}=0.01)$ among the genotypes for 1000 -grain weight (Table 1). The coefficients of variance (CV) for 1000 grain weight were $5.35 \%$. Averaged across genotypes, mean 1000 -grain weight was 46.2 g. 1000-grain weight among mung bean genotypes ranged from 42.6 to 55.6. Minimum 1000-grain weight were recorded for Mung Chakwal-06 (42.6) and maximum $1000 \mathrm{GW}$ of (55.6g) was recorded for Mung NM11 (Table 2). Earlier studies made by [7, 14, 15] also reported significant difference among mung bean genotypes for 1000-grain weight.

\subsection{Biological Yield $\left(\mathrm{kg} \mathrm{ha}^{-1}\right)$}

The analysis of variance showed highly significant genetic variation $(\mathrm{P}=0.01)$ among the genotypes for biological yield (Table 1). The coefficient of variance (CV) for biological yield was $4.88 \%$. Averaged across genotypes, mean biological yield was $864.21 \mathrm{~kg} \mathrm{ha}^{-1}$. Biological yield among mung bean genotypes ranged from 8888.9 to 13111.1. Minimum biological yield was recorded for KM-1 (8888.9 $\left.\mathrm{kg} \mathrm{ha}^{-1}\right)$ and maximum of Biological yield (13111.1 kg ha ${ }^{-1}$ ) was recorded for NM-92 (Table 2). The present findings are in close conformity with the earlier findings of $[8,16,17,18]$.

\subsection{Grain Yield $\left(\mathrm{kg} \mathrm{ha}^{-1}\right)$}

The analysis of variance showed highly significant $(\mathrm{P}=$ 0.01 ) among the genotypes for grain yield (Table 1). The 
coefficient of variance (CV) for grain yield was $9.31 \%$. Averaged across genotypes, mean grain yield was $2656.5 \mathrm{~kg}$ $\mathrm{ha}^{-1}$. Grain yield among mung bean genotypes ranged from 2022.2 to $3401.8 \mathrm{~kg} \mathrm{ha}^{-1}$. KM-1 recorded Minimum grain yield was of $2022.2 \mathrm{~kg} \mathrm{ha}^{1}$ and maximum grain yield of $3401.3 \mathrm{~kg} \mathrm{ha}^{-1}$ was recorded for NM-92 (Table 2). Reference [19] reported that time available for mung bean crop to produce adequate vegetative structure and then grain yield is often limited by hot or cold temperature and rainfall distribution. Similar results were also reported by $[6,7,16$, $20]$.

\subsection{Harvest Index (\%)}

The analysis of variance expressed highly significant genetic variation $(\mathrm{P}=0.01)$ among the genotypes for harvest index (Table 1). The coefficient of variance (CV) for harvest index was $8.51 \%$. Averaged across genotypes, mean harvest index was $25.5 \%$. Grain yield among mung bean genotypes ranged from 17.7 to $36.5 \%$. Minimum harvest index was recorded for NM-92(17.7\%) and maximum harvest index was recorded for Mung NM11 (36.5\%) (Table 2). Earlier studies made by $[8,16,17]$ reported significant variation among mung bean genotypes for harvest index.

Table 1. Mean squares for yield and associates traits of 14 mung bean genotypes during 2014.

\begin{tabular}{|c|c|c|c|c|}
\hline Traits & $\operatorname{Reps}(d f=2)$ & Genotypes $(\mathrm{df}=13)$ & Error $(d f=26)$ & CV(\%) \\
\hline Plant height & 3.52 & $677.29^{* *}$ & 4.63 & 2.43 \\
\hline Pod length & 0.05 & $0.98^{* *}$ & 0.19 & 4.95 \\
\hline Pods plant ${ }^{-1}$ & 2.45 & $23.90^{* *}$ & 1.15 & 5.74 \\
\hline Seeds pod ${ }^{-1}$ & 0.95 & $1.45^{* *}$ & 0.14 & 3.30 \\
\hline 1000 -grain weight & 41.30 & $36.60^{* *}$ & 6.10 & 5.35 \\
\hline Biological yield & 2253519 & $3983828^{* *}$ & 265171 & 4.88 \\
\hline Grain yield & 14843.00 & $371406.00^{* *}$ & 61216.00 & 9.31 \\
\hline
\end{tabular}

${ }^{* *}=$ Highly significant and Ns=non-significant.

Table 2. Mean performance for various traits of 14 mung bean genotypes during 2014

\begin{tabular}{|c|c|c|c|c|c|c|c|c|}
\hline Genotypes & PH & PL & PPP & SPP & TGW & BY & GY & HI \\
\hline KM-1 & 48.7 & 7.2 & 15.7 & 11.2 & 45.9 & 8888.9 & 2022.2 & 22.7 \\
\hline Chasma-98 & 82 & 9.2 & 17.5 & 11.1 & 48.6 & 10055.6 & 2578.9 & 25.6 \\
\hline Mung NM11 & 72.7 & 9.2 & 15.2 & 10.7 & 55.6 & 9377.8 & 3401.8 & 36.4 \\
\hline Mung Chakwal-06 & 102.7 & 8.7 & 24.6 & 11.3 & 42.6 & 10611.1 & 2555.6 & 24.0 \\
\hline Mung NM-06 & 87 & 9.7 & 18.5 & 11.5 & 49.6 & 10422.2 & 2739.2 & 26.2 \\
\hline Mung NCM-257-2 & 97.3 & 9.1 & 18.5 & 11.4 & 45.4 & 10144.4 & 2522.2 & 25.0 \\
\hline Mung AZRVI-06 & 95.7 & 9 & 15.9 & 11.5 & 42.9 & 9766.7 & 2474.7 & 25.4 \\
\hline VC-6321 & 105.7 & 8.6 & 18.6 & 11.7 & 44.2 & 11788.9 & 2733.3 & 23.2 \\
\hline VC-6369 & 93 & 9.1 & 15.7 & 10.3 & 45.7 & 9655.6 & 2351.7 & 24.3 \\
\hline VC-6370 & 98 & 8.8 & 18.1 & 10.9 & 48.3 & 10666.7 & 2881.3 & 27.0 \\
\hline VC-6368 & 100.7 & 8.8 & 22.5 & 11.9 & 43.1 & 12255.6 & 2546.7 & 20.7 \\
\hline NM-19-19 & 93 & 8.8 & 18.9 & 12 & 46.1 & 10811.1 & 2972.9 & 27.5 \\
\hline NM-92 & 77 & 8.8 & 19.5 & 9.3 & 43.3 & 13111.1 & 2311.1 & 17.7 \\
\hline Mean & 88.4 & 8.8 & 18.7 & 11.2 & 46.2 & 10546.8 & 2656.5 & 25.5 \\
\hline
\end{tabular}

$\mathrm{PH}=\mathrm{Plant}$ height $(\mathrm{cm}), \mathrm{PL}=$ Pod length $(\mathrm{cm}), \mathrm{PPP}=\mathrm{Pod}_{\mathrm{plant}}{ }^{-1}, \mathrm{SPP}=$ Seeds pod ${ }^{-1}, \mathrm{TGW}=1000-$ grain weight $(\mathrm{g}), \mathrm{BY}=\mathrm{Biological}$ yield $\left(\mathrm{kg}\right.$ ha $\left.{ }^{-1}\right), \mathrm{GY}=$ grain yield $\left(\mathrm{kg} \mathrm{ha}^{-1}\right)$ and $\mathrm{HI}=$ harvest index $(\%)$.

\section{Conclusions}

Significant differences among mung bean genotypes were observed for all the yield traits which showed that there is sufficient variability to have an effective selection. Genotype Mung NM11 showed highest values pods plant ${ }^{-1}$, 1000-grain weight and grain yield and could be recommended for general cultivars in Kohat.

\section{References}

[1] Shil S and Bandopadhyay PK, 2007. Retaining seed vigor and viability of mug bean by dry Dressing treatments. J. Food Legumes 20: 173-75.
[2] Pakistan Bureau of Statistics (2014). Ministry for Food and Agric. Govt. of Pakistan, Islamabad.

[3] Smith SE, Sing KB and Malhotra R. S, 1991. Morphological and agronomic variation in North African and Arabian alfalfa. Crop Sci. 31:1150-1163.

[4] Shah GS, 1999. Assessment of genetic variation and heritability of yield components in mung bean (Vigna radiata L.) Wilczek) and mode of inheritance of resistance to MYMV in this crop. Thesis, Institute of Pure \& Appld. Biol. Bahauddin Zakariya Univ. Multan, Pakistan.

[5] Ali MA, Nawab NN, Rasool G and Saleem M, 2008. Estimates of variability and correlations for quantitative traits in Mungbean (Vigna radiata L.) J. Agri. Soc. Sci. 4 (4): 177179. 
[6] Zaid UI, Khalil IH and Khan S, 2012. Genetic variability and correlation analysis for yield components in mung bean (Vigna radiata L. Wilezek), J. Agri. Biol. Sci. 7 (11): 1990-1997.

[7] Begum S, Noor M, Rahman HU, Hassan G, Durrishawar, Ullah H, Alia and Ali F, 2013. Heritability estimates and correlations among flowering and yield related traits in mung bean genotypes, Brit. J. of App. Sci. Tech. 3 (3): 472-481.

[8] Tabasum A, Saleem M and Aziz I, 2010. Genetic variability, trait association and path analysis of yield and yield components in mung bean (Vigna radiata L. Wilczek). Pak. J. Bot. 42 (6): 3915-3924.

[9] Sriphadetl S, Lambrides CJ and Srinives P, 2013. Inheritance of agronomic traits and their interrelationship in mung bean (Vigna radiate (L.) Wilczek). J. Crop Sci. \& Biotech. 10 (4): 249-256.

[10] Rasul F, Cheema MA, Sattar A, Saleem MF and Wahid MA, 2012. Evaluating the performance of three mungbean varieties grown under varying inter-row spacing. The J. Animal Plant Sci. 22 (4): 1030-1035.

[11] Sarwar G, Sadiq M, Saleem M and Abbas G, 2004. Selection criteria in F3 and F4 population of mung bean (Vigna radiata L.). Pak. J. Bot. 36 (2):297-310.

[12] Khattak GSS, Ashraf M and Khan MS, 2004. Assessment of genetic variation for yield and yield components in mungbean (Vigna radiata L. Wilczek) using generation mean analysis. Pak. J. Bot. 36 (3): 583-588.

[13] Abna F, Golam F and Bhassu S, 2012. Estimation of genetic diversity of mung bean (Vigna radiata L. Wilczek) in Malaysian tropical environment. Afr. J. Microb. Res. 6 (8): 1770-1775.
[14] Derya OY, Emin AA and Celal Y, 2006. Genetic variability, correlation and path analysis of yield, and yield components in mung bean (Vigna radiata L.). Turk J. Agric. 30: 183-188.

[15] Srivastava RL and Singh G, 2012. Genetic variability, correlation and path analysis in mung bean (Vigna radiata $\mathrm{L}$. Wilczek). Indian J. Life Sci. 2 (1): 61-65.

[16] Tiwari A, Tiwari JK and Mishral SP, 2012. Genetic divergence analysis in mung bean (Vigna radiata L. Wilczek). Intl. J. Food, Agric. Veter. Sci. 2 (3): 64-70.

[17] Ahmad HB, Rauf S, Rafiq CM, Mohsin AU and Umar, 2014. Genetic variability for yield contributing traits in mung bean (Vigna radiate L.). J. Glob. Innov. Agric. Soc. Sci. 2 (2): $52-$ 54.

[18] Divyaramakrishnan CK and Savithramma DL, 2014. Tailoring genetic diversity of mung bean (Vigna radiata (L). Wilczek) germplasm through principal component and cluster analysis for yield and yield related traits. Intl. J. Agron. Agri. Res. 5 (2): 94-102.

[19] Soltani A and Hammer GL, 2006. Modeling chickpea growth and development, phonological development. Field Crop Res. 99:1-3.

[20] Abbas G, Asghar MJ, Shah TM and Atta BM, 2010. Genetic diversity in mung bean (Vigna radiata L.) Wilczek germplasm. Pak. J. Bot. 42 (5): 3485-3495.

[21] Malik SA, Bakhash A, Asif MA, Iqbal U and Iqbal SM, 2010. Assessment of genetic variability and interrelationship among some agronomic traits in mung bean. Int. J. Agric. Bio., 12 (1): 81-85. 